\title{
The study of religion(s) in Western Europe (II): Institutional developments after World War II ${ }^{1}$
}

\author{
Michael Stausberg
}

It is only in recent years that the taboo against studying the history of the study of religion(s) under Fascist regimes, especially in Nazi Germany, has been broken. Horst Junginger has recently remarked: 'It took two generations to arrive at a distance great enough for a less biased and more objective stance on the issue' (Junginger, 2008a, p. 2). The time-frame of two generations before reaching the necessary historical distance that generates a historical interest in past scholarship not only applies to such sensitive periods as Fascism/National Socialism. For, while there now are several works on the formative period of the study of religions(s) and some important contributions on Fascism/National Socialism, not much has been published on post World War II developments, ${ }^{2}$ despite the fact that the study of religion(s), like many related disciplines, has experienced a further growth after the war. Moreover, the study of religion(s) has undergone a transformation in the period beginning with the 1960s. ${ }^{3}$ In some countries these developments have taken place earlier, in others later, with various differences but also some common elements. Not only have departments and chairs grown numerically on an unprecedented scale since then, but the intellectual framework of the study of religion(s) has changed considerably since the 1970s. In the present article, however, we will look at the institutional and organizational framework, the growth of social-scientific approaches to the study of religion(s), and last but not least, the reflections of the changing religious landscapes of Western Europe, on the academic community.

\section{Geopolitics and scholarship}

With the political division of Europe after World War II the notion of Western Europe has obtained a new political dimension. Many Western European countries received economical support from the US via the Marshall plan and most joined the NATO. With the falling of the so-called Iron Curtain the scholarly communities and discourses in Eastern and Western Europe became effectively disconnected and mutually isolated; 'studies of religion carried out in countries under communist rule were widely ignored in western countries' (Pye, 2001, p. 326). The new geopolitical circumstances that tied Western Europe to North America are also reflected in scholarship on religion. The migration of key scholars such as Tillich, Wach, and Eliade from Europe to the United States created further transatlantic links and scholarly networks.

For the United States, theoretical, ideological, and institutional consequences of the Cold War for the reinvention or establishment of Religious Studies have been tentatively sketched by

\footnotetext{
${ }^{1}$ Part I of the present series was published in issue 37/4, 204-318 (= Stausberg, 2007). The third and final part will be published in 2009 .

${ }^{2}$ The main exception is Platvoet's work $(1998,2002)$ on the study of religion(s) in the Netherlands.

${ }^{3}$ In this respect, Western Europe is no exceptional case; see Alles, 2007, p. 304: 'The 1950s and especially the 1960 s were a formative period for the study of religion almost everywhere in the world.'
} 
US American scholars (see Martin, 2001; McCutcheon, 2004). ${ }^{4}$ Can something similar be claimed for Western Europe ${ }^{5}$ Apart from the trivial observation that most Western European scholars of religion were anti-Communist and pro-religion and that some may or may have not seen their work as part of a project of Western self-affirmation, extant scholarship has not even began to address these issues. ${ }^{6}$ Compared to the United States, however, the situation in Western Europe is more complex. Not only was there no country-with the possible exception of Britain and France - that had the same ambition and abilities to become a super power on a scale comparable with the Soviet Union, but what is true for one European country simply may not apply to another. Given the present lack of research and knowledge, claims such as those made by McCutcheon for the United States, namely 'that one cannot study the establishment of the Humanistic study of religion ... without taking into account the Cold War funding context' (McCutcheon, 2004, p. 57), will be difficult to warrant in the Western European context. ${ }^{7}$

The end of the Cold War did not lead to an immediate recovery of academic relations with Eastern Europe. Linguistic barriers that already disconnect scholarship in several Western European countries from each other (Stausberg, 2007, p. 295) seem for most scholars even more insurmountable with regard to Eastern Europe-unless scholars from both areas communicate in English (or in French). The effects of the eastward enlargement of the European Union remain to be seen. Also the impact of the so-called War on Terrorism on scholarship on religion in Western Europe remains to be analyzed. ${ }^{8}$ And, even if the Cold War is over, political correctness continues to hamper scholarship everywhere (see Pye, 2001).

\section{Post World War II developments in Germany}

In Germany, the liberation from the Nazi regime resulted in the dismissal of some scholars who had been supporters, sympathizers, opportunists, or collaborators. ${ }^{9}$ While there was no way for the Tübingen Indologist and religious historian Jakob Wilhelm Hauer to return to an academic position, some others such as Gustav Mensching (Bonn) and Rudolf Franz Merkel (Munich), a student of Otto, were temporarily dismissed, but later on the bans on them were lifted. Interestingly, several German scholars with well-known Nazi leanings actively participated at the IAHR congresses in 1955 (Rome) and 1960 (Marburg) (see Junginger,

\footnotetext{
${ }^{4}$ A Canadian scholar (Wiebe, 2001) adopts a more skeptical attitude and finds no relevant evidence of a heavy Cold War impact on religious studies scholarship.

${ }^{5}$ Note one main difference. Whereas ' $\mathrm{t}$ ] he centrality of religion to American society ... was nowhere more evident than during the Cold War period' (Martin, 2001, p. 214), the same period has witnessed a decline of organized religion throughout Western Europe. Furthermore, it is unclear whether the Cold War ideology was, at least in several Western European countries, 'a religiously based' ideology, as Martin (2001, p. 215) asserts for the United States.

${ }^{6}$ The edited volume by Doležalová/Martin/Papoušek, 2001, assembles some fragments of a much larger puzzle.

${ }^{7}$ It seems to me that McCutcheon in his study points to a possible temporal correlation between new funding options as a result of the higher education investment made because of the perceived Soviet threat on the one hand and the changes in the 'disciplinary makeovers' $(2004$, p. 54) on the other hand, but it remains unclear whether there is a causal relation at play. An appeal to cynicism is hardly sufficient as a scholarly argument.

${ }^{8}$ The demand for Islamic Studies has increased, but in institutional terms Oriental Studies have benefited more from this development than Religious Studies departments.

${ }^{9}$ A famous example is Walther Wüst (1901-1993), maybe the 'archetype of a politically engaged Nazi scholar' (Junginger, 2008, p. 107). This scholar of Indology, comparative linguistics/mythology and religious studies acted as vice chancellor of the University of Munich (1941-1945). After the war he was imprisoned and became a persona non grata in academic circles. Junginger regards him 'as the perfect scapegoat whose undeniable guilt ought to bar the incriminations of many others from consideration' (2008b, p. 163).
} 
2008b, pp. 163-165). At the Marburg congress (1960), even Hauer 'and a whole "delegation" of the former Amt Rosenberg' (Junginger, 2008b, p. 165) took part. ${ }^{10}$

But there also were some new developments. One occurred at the Freie Universität in Berlin, founded in 1948 by students, citizens, and politicians, with the help of the American occupying power. There, upon the initiative of the German-American theologian and philosopher Paul Tillich (1886-1965), a chair and department for the study of religion was established where Tillich would regularly teach whenever he visited Berlin. Apparently what he perceived as the pseudo-religious elements of National Socialism had convinced Tillich of the necessity of a critical study of religion(s). ${ }^{11}$ The newly created chair was assigned to Tillich's former assistant Walther Braune (1900-1989) who is mainly known for his work on Arabic/Islamic historiography, and for providing a philosophical/theological reading of the history of the contemporary Middle East (Braune, 1960). After Braune's retirement the chair was split into two: a chair in Islamic Studies, held by Fritz Steppat (1923-2006), and a chair in 'the study of religion on the basis of the philosophy of religion', created for Klaus Heinrich (b. 1927), a founding student member of the university. Heinrich became famous in Berlin and beyond for his skills as an orator-being a speaker rather than a writer, many of his publications are reconstructed on the basis of recordings and notes of his students-, his teaching style, his immense learning and his political commitment to the ideals of a 'free' university. His work, which adopts key-elements from Tillich ('origins') and Freud ('repression'), moves in the borderland between Greek mythology (Oedipus!) and philosophy. Many of his texts provide a philosophical-psychoanalytical exegesis of myths that takes visual culture (modern arts, the Renaissance) as its point of departure. ${ }^{12}$ Heinrich's dense style, often difficult to follow for the non-initiates, won him the prestigious Sigmund Freud-Award for Scientific Prose in 2002. Heinrich's approach to the study of religion is too unique and personal to be copied by others, but he had many students who were fascinated by his charisma.

Another new development centered on Hans-Joachim Schoeps (1909-1980), a former student of Joachim Wach. Schoeps is described as 'one of twentieth-century Germany's most provocative and fruitful scholars' (Lease, 1997, p. 655). Before the war, Schoeps had for many years actively worked for a conciliation of National Socialism and Judaism. He therefore had emigrated only very late and both his parents were killed. After his return from emigration in Sweden, in 1950, as an act of reparation, Schoeps was appointed to an ad personam chair in 'religious and intellectual history' at the University of Erlangen. Based on the philosophy of Dilthey, Schoeps tried to give a new turn to Geistesgeschichte (i.e. intellectual history, not to be confused with the history of ideas) as the study of "zeitgeist" (see Schoeps, 1959 [with useful didactical examples]). This amounted to a reconstruction of the main thematic prevailing at a given period and analyzing the different and often contradictory positions reacting to that thematic. He also published a successful textbook on religion (Schoeps, 1961, several re-editions, also in paperback; English as The religions of mankind [1966] or An intelligent person's guide to the religions of mankind [1967] respectively). Schoeps is internationally best known for his various works on Christian-Jewish relations and for his much disputed amalgamation of Jewish and Christian thought. Schoeps had a reputation of being a fascinating teacher. He devoted much of his work to the history of Prussia; his philo-Prussianism, however, turned increasingly unpopular since 1968. On Schoeps' retirement, his chair was transformed into one in political science (see J. Schoeps, 2000). Through a renewed concordat with the Vatican any non-Christian appointee would be

\footnotetext{
${ }^{10}$ Benavides, 2001, p. 228 points to 'distressing' continuities in Hauer's post World War II work.

${ }^{11}$ Information provided by Karl-Heinz Kohl (letter to the author, August 20, 2006).

${ }^{12}$ For a critical discussion of Heinrich's approach see Irion, 1989, pp. 298-302.
} 
excluded at the outset - an ironic fate for a chair originally created as an act of reparation towards a Jewish scholar. ${ }^{13}$

Under National Socialism, new university institutes in the study of religion(s) had been created at the newly created Reichsuniversität Straßburg (founded by the Nazis in 1941 and dissolved in 1944) ${ }^{14}$ as well as in Greifswald and Halle. The two latter cities are in East Germany. The German Democratic Republic created increasingly unfavorable political and ideological circumstances for the study of religion(s). In Leipzig, the only remaining stronghold, the history of religions suffered from isolation and marginalization (see Rudolph, 1992, pp. viii-xi). After reunification, the department at Leipzig was reestablished in $1992 .{ }^{15}$ Apart from Leipzig, on the territory of the former GDR, the study of religion(s) is now grounded in four departments. All current professors are from West Germany. Erfurt stands out as a main center. With currently seven positions, it is Germany's largest department. ${ }^{16}$ Most other departments at German universities have no more than one or two chairs.

\section{Further institutional growth in France, Finland, and Spain}

In France, it seems that the German occupation and the Vichy regime had had a lasting impact: French sociologist of religion and scholar of laïcité Jean Baubérot (b. 1941) argues that it were these historical experiences which destroyed the walls that hitherto had separated the 'two Frances', i.e. the Catholic and the laic one (Baubérot, 2002, pp. 60-61), creating a new atmosphere for a renewed study of religion. Accordingly, the $5^{\text {th }}$ Section of the EPHE massively expanded (see part I = Stausberg, 2007, p. 306). Also in other countries, from Sweden and Norway to Italy, where the establishment of the study of religion(s) was accomplished by the 1930s, the number of chairs and department has continued, if not expanded (see also below). For now, we shall look at two countries which have emerged comparatively late on the scene.

In Finland, institutionalization took place much later than in neighboring Sweden (see Anttonen, n.d.; Holm, n.d.; Helve, 2004). The first chair was established at Åbo Akademi, Finland's Swedish university in Åbo/Turku, in 1960. The first appointee was Helmer Ringgren (b. 1917), a scholar of Old Testament and neighboring religious history, followed by Sven S. Hartman (1917-1988), a student of Widengren whose dissertation was on ancient Iranian religion. Both were Swedish scholars with a background in the Uppsala-school and both would some years later take up positions in Sweden: Ringgren as professor for Old Testament in Uppsala and Hartman as professor of the history of religions in Lund, when a chair was established there. The third appointment was the Latvian theologian and historian of religions, Haralds Biezais (1909-1995), who had studied with Gustav Mensching when the

\footnotetext{
${ }^{13}$ Schoeps' son Julius (b. 1942), a historian, continues to work on Jewish-German relations at the Moses Mendelssohn Zentrum für europäisch-jüdische Studien (MMZ) in Potsdam. He also acts as the president of the Gesellschaft für Geistesgeschichte (Society for Intellectual History), founded by his father in 1958, and he is one of the editors of the Zeitschrift für Religions- und Geistesgeschichte founded by his father jointly with the church historian Ernst Benz (1907-1978) in 1948.

${ }^{14}$ At Strasburg the chair was occupied by Otto Huth, a former assistant of Hauer and a committed Nazi; on Huth see Junginger, 1999, pp. 248-268.

${ }^{15}$ Holger Preißler (1943-2006), an expert on the pre-Islamic religions of Arabia, had been professor of the History of Religions since 1985. He served as an import figure of transition and was instrumental in reestablishing the department.

${ }^{16}$ Founded in 1999, the department was composed to reflect the 'pluralism' of religious traditions in Europe. Accordingly the chairs are assembled to represent main currents of European religion: Protestant Christendom, Orthodox Christianity, Judaism, and Islam. Moreover, there is a chair of comparative religion (held by an expert in Roman religion) as well as an honorary chair in Greek and Roman religion and a junior chair in ancient religions.
} 
latter held an appointment at Riga. Via Mensching, Biezais was greatly influenced by German scholarship centering on the notion of the holy. Biezais' main scholarly contribution is a series of books on Latvian mythology and folk religion, but he also involved himself in methodological issues. ${ }^{17}$ At the Finnish university in Turku a chair was established in 1963, to be taken by Lauri Honko (1932-2002), an internationally well-known scholar of Finnish 'folk' religion and ritual (Pentikäinen, 2005). In 1970, Honko's disciple Juha Pentikäinen (b. 1940), who further advanced the study of 'folk' religion, became the first professor of comparative religion at the University of Helsinki, where this chair is situated in the Faculty of Theology. However, the study of religion is also a subject at the Faculty of Arts, and the Department of Comparative Religion (as it is now called) is uniquely situated in both Faculties. In 2000, a second chair was created (in the Faculty of Arts) which is held by René Gothóni (b. 1950), whose main work is on (Buddhist) monasticism and (Greek Orthodox) pilgrimage with an emphasis on comparative perspectives and methodological issues. Gothóni is one of the few remaining scholarly protagonists of an explicitly hermeneutical approach to the study of religion(s).

In Spain a first chair in the History of Religions was created in 1954. This development has to be seen in the context of the so-called liberal years (1951-1956) in matters of culture and education of the Franco regime. The chair-holder, Ángel Álvarez de Miranda (1915-1957) who had studied with Pettazzoni while he served as director of the Instituto Español de Lengua y Literature in Rome (1948-54), was a personal friend of the then minister of education. This episode once more illustrates the often arbitrary elements that account for developments in the history of science. However, the chair was not firmly established, and after Álvarez de Miranda's premature death the changed political circumstances were not favorable to the continuation of this academic enterprise. ${ }^{18}$ Religious studies were then mainly perpetuated by scholars grounded in other academic disciplines. Akin to France and Italy, many Spanish scholars are involved in the study of ancient Mediterranean religion as well as in the study of Islam and Judaism. ${ }^{19}$

In a disciplinary sense the study of religion(s) has flourished since 1992 and is now taught at several Spanish universities (Diez de Velasco, 1995; Wiegers, 2002a). ${ }^{20}$ One of the most prominent public figures of religious studies during the past decades has been the Catholic priest Raimon Panikkar (b. 1918) who after studying in Spain and Germany (Bonn) and spending many years in India held positions at Harvard University (1968-1971) and as professor of Religious Studies in Santa Barbara (1971-1978). He now lives the life of a semirecluse in a village near Barcelona. Panikkar is mostly known for his many books centering on the philosophy of religion and radical pluralistic, but at the same time holistic theology of religions $^{21}$ as well as for his work on inter-religious or inter-cultural dialogue which he epitomizes in his own biography. Although his approach hardly qualifies as non-theological, Panikkar's credentials, colorful personality, wide network, and international reputation apparently helped the study of religion(s) to take shape in Spain where it is still facing the somewhat paradox challenge of the National Spanish Catholic ideology on the one hand and anticlericalism and antireligious ideologies on the other. ${ }^{22}$ Among the younger generation,

\footnotetext{
${ }^{17}$ On Biezais see now Leitāne, 2008.

${ }^{18}$ For the circumstances leading to Álvarez de Miranda's appointment and reasons for the failure to continue the chair as well as for Álvarez de Miranda's scholarly work see Diez de Valesco 2007.

${ }^{19}$ I owe this observation to Francisco Díez de Velasco.

${ }^{20}$ While not directly caused by these, this development must be seen in the context of the political transition from dictatorship to democratic constitutional monarchy that occurred in 1975-1978. Reasons for the delay in the establishment of the non-confessional study of religion vis-à-vis the political transition are discussed by Diez de Velasco, 1995.

${ }^{21}$ For a critical discussion see Kormulainen, 2005.

${ }^{22}$ This was pointed out to me by Francisco Díez de Velasco.
} 
Francisco Díez de Velasco (b. 1960) is active on the European stage and has published two massive introductory books $(2002,2005)$. Apart from these textbooks, Spanish scholarship is now having two journals (Ilu and Bandue) and an association which arranges biannual conferences.

\section{The founding of scholarly associations after World War II}

It was only after World War II that an international as well as several national professional associations were formally established. The first of these, the Dutch Association of Historians of Religion (NGG = Nederlands Genootschap van Godsdiensthistorici) was formed on the initiative of Gerardus van der Leeuw (1890-1950), in the run-up to the conference in 1947. The International Association for the Study of the History of Religions (IASHR) was set up in 1950 at the occasion of the international conference in Amsterdam. Van der Leeuw, who since 1918 had a chair in 'History of religions in general and the history of the doctrine concerning god' at the Rijksuniversiteit Groningen, was the dominating figure on the Dutch scene. He served as the first president of the international association, followed by Pettazzoni after van der Leeuw's untimely death shortly after the association was founded. At the second post World War II conference arranged by the society, its name was changed to the one still in use: International Association for the History of Religions (IAHR). ${ }^{23}$

The initial conference and the establishment of the international association were followed by the founding of some affiliated national organizations. The German association (Deutsche Vereinigung für Religionsgeschichte) was founded in 1950, the Italian society (Società Italiana di Storia delle Religioni) in 1951 and the British Association for the History of Religions in 1954. Sweden even had two societies, one based in Stockholm (Svenska Religionshistoriska Samfundet) and one based in Uppsala (Samfundet for religionshistorisk forskning). Norway had one affiliated national association (Norsk Religionshistorisk Forening), founded in $1953 .{ }^{24}$ Only France had a national society prior to World War II, and it also is the only one whose name commemorates a founding scholar: the Sociéte ErnestRenan: Société Francaise d'Histoire des Religions, founded in 1919. The activities of this society had been disrupted during the war and were resumed in $1952 .{ }^{25}$

\section{From history to science(s)}

All of the above-mentioned scholarly associations have the word 'history' in their names, and it seems that there was a broad consensus that an historical approach to religion was what made the field into a discipline, thereby distinguishing it from other scholarly enterprises studying religion. This consensus, however, weakened in the decades to come, and hence in the early 1990s there was an attempt to replace 'history' with 'study' in the name of the international association. This motion was eventually rejected under the presidency of Ugo Bianchi (1922-1995) who himself vigorously resisted such as change. As a scholar, Bianchi clearly favored a historical-comparative approach and doubted the epistemological possibility

\footnotetext{
${ }^{23}$ According to Bleeker, 1955, p. 236, the president (Pettazzoni) found the previous name 'somewhat cumbersome' and therefore proposed to change the name to its current form: 'It was decided to overlook that this new name is not entirely correct English and to accept the proposal of the President for practical reasons.'

${ }^{24}$ The association later became inactive and was reconstituted in 1990/91. (Information generously provided by Einar Thomassen.)

${ }^{25}$ Apart from these associations, Bleeker, 1955, p. 238, lists the following "membergroups" (sic): The Japanese Association for the Science [!] of Religion; "Théonoé": Société d'Etudes Mythologiques (Belgium); International Organisation of Old Testament Scholars.
} 
of a larger view of the science of religion as a discipline encompassing history as well as sociology and psychology.

The French and Italian associations have maintained their original name. However, the Dutch, British and the German associations have in 1988 (Britain), 1989/1992 (the Netherlands), ${ }^{26}$ and 2005 (Germany) respectively replaced 'history' by 'study' or 'science' in the respective names. Most of the younger associations such as the Swiss, Spanish, Austrian, and Greek associations founded in 1977, 1993, 1996 and 2003 respectively have opted for 'science', 'sciences', or 'study'. 27

The latest national association to appear on the scene, the Associação Portuguesa para o Estudo das Religiões (APERLG), was founded in $2007 .^{28}$ It held an inaugural conference in April 2008 and plans to hold regular conferences in the future. Despite the existence of a national association, there are no positions for the subject at Portuguese universities, and the study of religion(s) is merely taught at one private university (the Universidade Lusófona de Humanidades e Tecnologias). ${ }^{29}$ Nevertheless, since 2002 there is a Portuguese journal, now entitled Revista Lusófona de Ciência das Religiões (formerly Revista Portuguesa de Ciência das Religiões). ${ }^{30}$ Interestingly, a main section of the first issue was dedicated to the problem of freedom of religion in Portugal.

The name-changes and the choice of names for the new associations are on the one hand attempts to strengthen the position of the subject or discipline in the increasingly competitive academic systems. On the other hand, the name changes reflect major shifts in the selfunderstanding of the field/discipline in developing a broader outlook or a more comprehensive perspective on its subject matter, ${ }^{31}$ in particular opening for social sciences perspectives. ${ }^{32}$ On a scholarly level, this change is reflected in Frank Whaling's widely known edited work Contemporary Approaches to the Study of Religion, the second volume of which deals with social sciences such as psychology, sociology, and social/cultural anthropology (Whaling, 1985). One also needs to recall that rubbing shoulders with social sciences may have been part of a strategy to side with disciplines that got an increased attention and a larger share of institutional funding than institutionally declining branches of humanities such as philosophy or the study of antiquity (see Alles, 2007, p. 311).

A competency in history and a solid training in dead or 'exotic' languages are nowadays in many places no longer generally assumed to be key elements in the formation and competency of scholars. Accordingly, the historical-philological method which to some extent used to enjoy a position of professional pride in earlier scholarship is nowadays almost marginalized in some contexts and solid training in this domain is increasingly difficult to obtain. Instead, the methodological arsenal of the field is diversifying and there is an increasing tendency to focus on contemporary religions and religiosities (see also Sharpe, 2005 , p. 43), often of the alternative variety, and on migrant or diaspora groups. It is no exaggeration to say that the study of European Hinduism(s) or Islam(s) by now even seems to

\footnotetext{
${ }^{26}$ Jan Platvoet generously provided detailed information on the name change of the NGG from Nederlands Genootschap van Godsdiensthistorici to Nederlands Genootschap voor Godsdienstwetenschap (Dutch Association for Science of Religions). The change was discussed and decided in 1989 and ratified in 1992.

${ }^{27}$ However, the Romanian Association for the History of Religion (founded in 1997, and a member of the EASR since 2002) has opted for history instead of study, probably because of the strong French and Italian impact on Romanian scholarship in this field of study.

${ }^{28}$ I am indebted to Steffen Dix, the current vice-president of the association, for providing information.

${ }^{29}$ This course is taught by the current President of the association, Paulo Mendes Pinto.

${ }^{30}$ See http://cienciareligioes.ulusofona.pt/index.htm (accessed April 30, 2008).

${ }^{31}$ Some relevant changes in scholarship will be discussed in Part III.

${ }^{32}$ See also Sharpe, 1986, p. 308: 'It has become increasingly important in recent years for religious studies to affirm its right to academic recognition in what has sometimes been an unfriendly academic environment, and this has generally involved a greater approximation to the methods and approaches of the social sciences'.
} 
exceed the study of these religions in former periods and their places of origin; Hindu and Muslim diasporas now seem to attract greater scholarly attention than early Indian and Islamic literature, and it is in many places easier to get such apparently more political 'relevant' research founded. These developments reflect changing religious realities in Western Europe as well as the impact of migration upon all Western European societies, for not to speak of changes in the system and politics of higher education.

\section{The academic differentiation of the field: social scientific approaches}

Given these developments, we need to broaden our outlook and take a look at the emergence and institutional development of social scientific approaches to the study of religion(s), with an emphasis on its interface with the more narrow disciplinary outlook adopted in this article. In the following, the development of the psychology, sociology, and anthropology of religion will be sketched - again with an exclusive focus on Western Europe.

Psychology of religion

Some eminent late nineteenth and early twentieth Century European psychologists such as Wilhelm Wundt, Pierre Janet, Theodule Ribot, Sigmund Freud and the psychoanalysts made important contributions to the emergence of a psychology of religion (Wulff, 1991, pp. 14-30). However, the psychology of religion did not develop into a well-established subfield of academic psychology. Professional academic psychology generally avoided religion as a field of study, while theologians in their turn were often suspicious of psychologists (Henning, 2000, p. 95). Nevertheless, many prominent scholars of religion such as Söderblom's successor in Uppsala, Tor Andræ (1885-1947), known for his works on Muhammad and Islamic mysticism (see Schimmel, 2005/1987), and Friedrich Heiler (1892-1967), author of a pioneer study of prayer $\left(1918 ; 1923^{5}\right)$, shared a vital interest in questions pertaining to the psychology of religion. They were not, however, trained in academic psychology.

The institutional establishment of the psychology of religion began in the Netherlands in the late 1950s, mainly as a branch of Pastoral Theology and, with one exception (Nijmegen), within Faculties of Theology (Platvoet, 2002, pp. 128-129). The Catholic University (Katholieke Universiteit) Leuven in Belgium has a centre for research in the psychology of religion, located in the Faculty of Psychology and Educational Sciences. ${ }^{33}$ The Frenchspeaking Catholic University of Louvain (UCL) at Louvain-la-Neuve also has a Centre for the psychology of religion, likewise located in the Faculty of Psychology and Education, and known, inter alia, for its studies of the psychology of religious development (Saraglou/Hutsebaut, 2001). In Sweden, some chairs in the psychology of religion have been established since the 1970s in Faculties of Theology (Wikström, 2000). Hjalmar Sundén (1908-1993) and his theory of religious role-taking (Sundén, 1959, 1966 ${ }^{4}$ [German 1966]; see Holm/van Belzen, 1995) has made a strong impact on the development of the psychology of religion in Sweden and beyond. ${ }^{34}$ Sundén also published an early introductory textbook (Sundén, 1974 (1981 ${ }^{3}$ ) [German 1982]). In Lund, Antoon Geels (b. 1946) pursues studies of mysticism with regard to several religious traditions. Together with his colleague from Uppsala, Owe Wikström (b. 1945), he published a textbook that is widely used in Scandinavia (Geels/Wikström, 1984, 2006 ${ }^{5}$ ). Apart from research in clinical, psychiatric, and methodological as well as theoretical questions, Wikström also works as a therapist and

\footnotetext{
${ }^{33}$ With the main position not being replaced, the future development of that centre is somewhat unclear at present.

${ }^{34}$ See Holm, 1997, for a further development of the theory.
} 
Lutheran priest. In recent years he has published several popular essay-books (translated in several languages). In Italy, mutual suspicion between the Catholic Church and academic psychologists and practical psychologists for a long time prevented the sporadic interest in the psychology of religion from developing systematically. However, in the 1960s the psychology of religion emerged as an academic subject at several ecclesiastical universities. Work in these institutions concentrated on Roman Catholicism and theoretical reassessments of psychoanalysis (Aletti, 1992). In 1995, the Italian Society for the Psychology of Religion (Società Italiana di Psicologia della Religione) ${ }^{35}$ was founded. It regularly arranges conferences on topics such as religious identity in a plural society, fundamentalism, and topics related to psychoanalyst traditions such as religious illusion. In Switzerland there is one chair in the psychology of religion (in Lausanne). In Germany there is not a single academic chair for the psychology of religion. Occasionally scholars in psychology departments do, however, address religious issues. ${ }^{36}$ In France and Britain not much research in the psychology is undertaken, but there is a MA program in the psychology at the University of London's Heythrop College (formerly a Jesuit institution), a specialist college that concentrates on Theology and Philosophy.

An International Association for the Psychology of Religion (IAPR) was founded as early as 1914 in Germany. Its activities, however, were repeatedly interrupted due to political circumstances. Moreover, the association largely owed its existence to the initiative of some single persons, mostly theologians who also dominated the board of the association. ${ }^{37}$ The academic vision of the board was largely confessional (if not apologetic) and not affine to the concerns of recent developments in academic psychology. Its constitution followed a topdown level rather than the principles of representative democracy. All these factors put the this association in a somewhat isolated position and a sort of dissenting pressure group of scholars started to arrange separate conferences (Nijmegen 1979). After the election of Finish psychologist and historian of religions Nils G. Holm (b. 1943), the author of a textbook (1985 $\left[2002^{4}\right]$; German translation), steps were taken to modernize the association and to open it up to a more non-confessional, non-theological agenda in line with the professionalization of this field of study. This policy has continued, and in the early years of the new millennium the association adopted a new constitution and new bylaws (van Belzen, 2002) and the two groups were subsequently assimilated. Since its inception, the International Association irregularly published a journal, the Archiv für Religionspsychologie/Archives for Psychology of Religion, which in recent years seems to have found a more solid basis.

In general, there are very few ties in Europe between the psychology of religion and the study of religion(s) in a more narrow sense. ${ }^{38}$ Both branches of scholarship largely navigate in separate intellectual worlds. Contemporary historians of religion are generally disinterested in the psychology of religion. For many psychologists theology rather than the study of religion(s) remains the main contact discipline, perhaps since theology is bigger, more visible institutionally, more practically minded or because the psychology of religion to a large extent focuses on Christians and Christianities.

\section{Sociology of religion}

\footnotetext{
${ }^{35}$ See http://www.psicologiadellareligione.it (last accessed April 25, 2008).

${ }^{36}$ For the complex history and contemporary situation of the psychology of religion in the German speaking countries see Henning, 2003.

${ }^{37}$ Kurt Krenn (b. 1936), the controversial Catholic theologian and subsequent bishop of St. Pölten (later resigned) was serving as its chairman in the 1980 s.

${ }^{38}$ Belzen, 2005 is one of the few scholarly articles on the psychology of religion by a European scholar in a mainstream study of religion(s) journal.
} 
The ties between the sociology of religion and the history of religions are somewhat closer. Some of the classical figures in the study of religion(s) such as Émile Durkheim and Max Weber were sociologists. However, religion was not their only interest. The development of the sociology of religion as a separate academic subject occurred only after World War II. An important step was the foundation of the Société Internationale de Sociologie des Religions/International Society for the Sociology of Religion in Leuven/Belgium in 1948, i.e., two years prior to the IA[S]HR. Since 1953 it has published an interdisciplinary journal, Social Compass: International Review of Sociology of Religion. One issue per year provides extensive bibliographical updates of the field. Over the decades the journal has changed its profile from a focus on Catholicism to the general sociology of religion (see Mejido 2004).

Among other specialized publications, there are the French Archives de sciences sociales des religions which continue the Archives de sociologie des religions (1956-). The changing title indicated a broadening of perspective to include the social sciences in general, including anthropology. The Italian journal Religioni e Società (1986-) also deserves mention. In Italy and even more so in France, but also elsewhere, historical and sociological perspectives are divided both in terms of scholarly practice and institutional framworks. In France one finds, besides the Société Ernest-Renan, the Association française de science sociale des religions. In 1993 the Centre d'Études Interdisciplinaires des Faits Religieux (Center for the Interdisciplinary Study of Religious Facts) was established at the École des Hautes Études en Sciences Sociales (EHSS), formerly the sixth section of the École Pratique des Hautes Études (founded in 1947). Currently, 25 scholars, 20 associated scholars and around 70 doctoral students work at this center.

There are no research institutions of a similar size in Germany and Britain. Here, however, the national sociological associations have subsections devoted to the sociology of religion. Many sociologists of religion such as James Beckford, Steve Bruce, Roberto Cipriani, Grace Davie, Karel Dobbelaere, Danièle Hervieu-Léger, Ingo Mörth, Thomas Luckmann, Hubert Knoblauch, David Martin, Arnaldo Nesti, Detlev Pollack, Carlo Prandi, and Liliane Voyé, were/are in sociology departments. Some others such as Peter B. Clarke, Volkhard Krech, Pål Repstad, Ole Riis, and Jörg Stolz are in departments of religion.

In Scandinavia, the academic institutionalization of the sociology of religion began in the 1970s and took place mainly in Religious Studies departments or church-affiliated institutions. ${ }^{39}$ Recently the originally Norwegian Tidsskrift for kirke, religion og samfunn (Journal of church, religion, and society) was transformed into the Nordic Journal of Religion and Society. Its second issue (vol. 18/2 [2005]) surveys the history and state of affairs in the sociologies of religion in Denmark, Finland, Iceland, and Norway (see also Beckford 2006).

Several European countries have research institutes which promote the sociological study of religion, particularly with regard to the changing position of Christianity and the churches. Examples include the Katholiek Sociaal-Kerkelijk Instituut in Nijmegen (the Netherlands) which initially launched Social Compass, ${ }^{40}$ the Arbeitsstelle Kirchliche Sozialforschung in Vienna (Austria), the Forschungsstätte der Evangelischen Studiengemeinschaft in Germany,

\footnotetext{
${ }^{39}$ At the University of Copenhagen a chair in the sociology of religion was established in 1969. The first appointment, however, was not a sociologist, but a historian of religions (Arild Hvidtfeldt [1915-1999]) who had mainly worked on Aztec and Greek religion. Before starting his academic career he was a politically committed Social Democrat; he had worked as a journalist and was active in the resistance movement. In an early survey work of the general history of religions he introduces religion as a phenomenon of society and holds that it is purposeful (with changing purposes in different contexts). He proposes to write religious history as a part of cultural history (Hvidtfeldt, $1961\left[1985^{8}\right]$ ).

${ }^{40}$ This journal was originally 'dedicated to the dissemination of a theoretically restricted sociography of Catholicism that, as the handmaiden of Scholasticism, aimed to combat and harness the dialectic of secularization and critique from "outside"” (Mejido, 2004, p. 25).
} 
the Research Institute of the Evangelical Lutheran Church of Finland, the Uppsala Institute for Diaconal and Social Studies and the Centre for Church Research in Norway. The Swedish and Finish research institutions have published surveys of the changing religious landscapes in their respective countries (Bäckström/Pettersson/Beckman, 2004; Kääriäinen/Niemelä/Ketola, 2005). A similar, but not church-related research center is the Observatoire des religions en Suisse at the University of Lausanne, currently directed by Jörg Stolz.

The main concerns of contemporary Western European sociologists include secularization, religious pluralism, new religious movements, bricolage, institutional deregulation, privatization, diffuse/invisible/implicit forms of religion, 'spirituality', 'secular religiosities', and the definition and the theory of religion. ${ }^{41}$ Religious change in contemporary European religious history lead scholars to reflect on such concepts as memory and tradition. While sociologists of religion almost exclusively occupy themselves with the study of contemporary religion, occasional some historians of religion have tried to follow the track of Max Weber by fruitfully applying sociological categories to the study of ancient religions. Noteworthy in this regard is Hans Kippenberg's (1991) attempt to situate the rise of ancient salvation religions in the context of the political structure of ancient cities. Kippenberg has repeatedly explored the fruitfulness of Weber's approach to the study of religion (Kippenberg, 2002; Kippenberg/Riesebrodt, 2001). ${ }^{42}$

\section{Anthropology of religion}

Ever since its beginnings as an academic discipline anthropology or ethnology has made a huge impact on the study of religion. Several early anthropologists have put forward influential theories of the origin of religion. Recall the pioneering studies by Herbert Spencer and Edward B. Tylor, who was appointed to the first chair of anthropology in Britain, and the subsequent studies of Andrew Lang, Robert Ranulph Marrett, and James G. Frazer. The German-Austrian ethnologist and Catholic missionary priest, Wilhelm Schmidt (1868-1954) challenged the underlying evolutionism of Victorian anthropologists with his theory that monotheism did not result from an evolutionary process but was the original religious state of mankind (Urmonotheismus) which then developed into different forms. ${ }^{43}$ The German ethnologist, Adolf Ellegard Jensen (1899-1956) is mostly known for having introduced the concept dema-deities which came to be employed by a host of scholars (see Zerris/Ciattini, 2005).

Up to World War II, questions of evolution and diffusion of religion and a focus on 'primitive', i.e. original, primal, early religion characterized all branches of the study of religion including sociological (Durkheim) and phenomenological (van der Leeuw) approaches. In the course of time, however, anthropological studies began to focus on social relationships and contexts as well as psychological and social functions and structures. Moreover, in anthropology the 'revolt against evolutionism ... was inspired by the development of fieldwork methods' (Gellner, 1999, p. 16). In Britain, these developments are linked to scholars such as Alfred Reginald Radcliffe-Brown (1881-1955) and Bronislaw Malinowski (1884-1942) as well as, later, Edward E. Evans-Pritchard (1902-1973).

\footnotetext{
${ }^{41}$ See Voyé (2004) for a recent survey by a European author.

${ }^{42}$ For an assessment of Kippenberg's work see von Stuckrad, 2003.

${ }^{43}$ On Schmidt see Henninger/Ciatini, 2005. On Schmidt's anti-Semitism and anti-Judaism see Mischek, 2008.
} 
Evans-Pritchard wrote several important contributions to the study of religion ${ }^{44}$ based on his fieldwork among the Azande and the Nuer. For example, his 1937 book on witchcraft later gave raise to a debate on such issues as rationality and translation (see Gellner, 1999, p. 28). Africa was also the main field of study for the so-called Manchester school (on which see now Evens/Handelman, 2006), initiated by Max Gluckman (1911-1975), which focused on social conflict and order. Among the protagonists of this school, Victor Witter Turner's (1920-1983) well-known studies on ritual and ritual symbolism continue to be popular in Religious Studies departments. Whereas previous studies had tended to emphasize the stabilizing effect of rituals and religion, Gluckman and Turner also paid attention to the role played by rituals for inversion, resistance and cultural creativity. While British scholarship was more interested in social structure, in France Claude Lévi-Strauss (b. 1908) drew attention to classificatory and cognitive structures that underlie culture. That line of thinking was subsequently further developed in Britain by Edmund Ronald Leach (1910-1989) and Mary Douglas (1921-2007) whose work, however, also relates religion closely to social formations. $^{45}$

Since the late 1960s, anthropology has been accused of being static, colonial, androcentric, and elitist. Similar criticism has later also targeted the study of religion(s), but post-colonial, post-modernist and post-structuralist critiques have affected anthropology much more than they have the study of religion. The so-called 'crisis of representation' experienced by anthropology since the 1980s was not perceived as a similar challenge in the study of religion(s), at least in Western Europe. Like anthropology, the study of religion(s) has recently focused more on objects, media, and the movement of things and people.

Courses (modules) on the anthropology of religion are taught at various universities throughout Western Europe, both in anthropology and religion departments. The Department of Religious Studies at Lancaster University offers a B.A. in Anthropology of Religion, and Department of Divinity and Religious Studies at the University of Aberdeen offers a postgraduate degree (MLitt) in Social Anthropology of Religion. Both Departments have specialized staff trained in anthropology, Paul Heelas, known for his studies of the New Age (1996) and recent religious transformations (Heelas/Woodhead, 2005), in Lancaster, and Martin Mills, who works on Tibetan Buddhism, in Aberdeen. Nevertheless, in Western Europe the anthropology of religion is institutionalized to a much lesser degree than either the psychology or the sociology of religion. ${ }^{46}$ The field has no separate scholarly association, no specialized chairs, ${ }^{47}$ no specialized journals, ${ }^{48}$ and no specific reference works. However, there are several introductory textbooks in all major European languages.

\footnotetext{
${ }^{44}$ His review of earlier theories of primitive religion (1965; translated into French, Italian, German, and other languages) was widely used even in religious studies department.

${ }^{45}$ On Leach see Tambiah, 2002; on Douglas see Fardon, 1999.

${ }^{46}$ Karl-Heinz Kohl (letter to the author, August $20^{\text {th }}$, 2006) suggests that since anthropology traditionally studies small-scale and homogeneous societies where religion is not institutionally differentiated, anthropology, in line with the discipline's holistic approach, has not been subdivided into the anthropology of religion/technology/economy etc.

${ }^{47}$ The ancient chair of religion of 'non-civilized' (later: 'oral') people held by respectively Léon Marillier, Marcel Mauss, Maurice Leenhardt, and finally Lévi-Strauss at the Sorbonne/ÉPHE in Paris has been abolished in 1974. In its place an increasing number of positions specializing on specific areas were established. At present, several of these chairs are held by trained anthropologists, including the ones on the religions of the South American Indians, religions of Oceania, Black Africa (actually two chairs), South Asia, 'religious ethnology of Europe', 'contemporary Christianity in non-European societies', and 'religious currents in the Russian and Russianized world'.

${ }^{48}$ General journals including Anthropos, Ethnologie française, Paideuma, and Terrain regularly publish articles on religion.
} 
Despite this lack of institutionalization, however, many Western European anthropologists have addressed religious issues in their publications, and anthropological approaches have been increasingly influential even in the study of religions that were once the preserve of scholars using historical-philological methods. For example, important anthropological studies include the French anthropologist Louis Dumont's (1911-1998) controversial and widely translated structuralist study of the caste-system (1967) and British anthropologist Chris Fuller's (b. 1949) insightful study of popular Hinduism (1992). Similarly, scholars of ancient Mediterranean religions have enriched their work by drawing on insights from cultural anthropology.

Relatively few scholars working in Western European religious studies departments have small-scale, indigenous people as their main area of specialization. Current exceptions include Håkan Rydving (Bergen), a specialist of Sami religion and languages, Gilberto Mazzoleni (Rome), and Armin Geertz (Århus), an expert on the Hopi. European anthropologists who are well-known for their work on religion include Maurice Bloch, Simon Coleman, André Droogers, David Gellner, Kirsten Hastrup, Luc de Heusch, Bruce Kapferer, Karl-Heinz Kohl (trained in Religionswissenschaft), Vittorio Lanternari, Ioan Lewis, Birgit Meyer, and Harvey Whitehouse.

\section{More than an institution: Eranos}

In 1933, invited scholars began to meet annually in Ascona (Switzerland). ${ }^{49}$ These somewhat elitist eight day meetings were at first convened by Olga Fröbe-Kapteyn (1881-1962), somewhat in the tradition of the female patrons of literary salons (Hakl, 2001, p. 429). It seems that the name 'Eranos' for these meetings was suggested to her by Rudolf Otto (Hakl, 2001, pp. 92-96). Fröbe-Kapteyn stressed that the meetings had no rigid program or plan but were inspired by an archetypal spirit to which she had intuitive access (Hakl, 2001, p. 317). The meetings were substantially funded by the American Bollingen Foundation which was initially devoted to disseminating the work of Carl Gustav Jung (1875-1961). ${ }^{50}$ Until 1951, when he attended for the last time, Jung had made a strong impact on the spiritual and intellectual atmosphere prevailing at the meetings.

The list of invited speakers at the Eranos-meetings reads like a who-is-who of the most prominent and outstanding scholars in the field of religious studies in the broadest sense, among them Gerardus van der Leeuw, Friedrich Heiler, Heinrich Zimmer, Jakob Hauer, Martin Buber, Puech, Erich Neumann, Karl Kérenyi, Leo Baeck, Gilles Quispel, Henry Corbin, Gershom Scholem, Mircea Eliade, ${ }^{51}$ Raffaele Pettazzoni, Karl Löwith, Paul Radin, Joseph Campbell, Giuseppe Tucci, D.T. Suzuki, Ernst Benz, Jean Daniélou, Paul Tillich, Gilbert Durand, Robert Charles Zaehner, and Eric Voegelin.

The first phase of the meetings was to some extent dominated by Jung; they focused on meditation, salvation, symbolism, spirit, and East/West. Beginning in the late 1940s the Swiss biologist Adolf Portmann (1897-1982) emerged as a dominant figure. ${ }^{52}$ Not only did he give more lectures than anybody else but his impact is also felt in the choice of topics which centered around questions of fundamental anthropology such as 'the human being', 'man [sic!] and time', 'man and rite', 'man and energy', 'man and earth', 'man and meaning', and 'man

\footnotetext{
${ }^{49}$ See Bauschulte, 2007, pp. 178-212 for the Weimar prehistory of these meetings and some of their protagonists.

${ }^{50}$ The Bollingen Foundation, named for Jung's country home in Bollingen (Switzerland), is best known for the Bollingen Series of books, the Bollingen Prize for poetry, and the fellowships it has awarded. The Bollingen Foundation became inactive in 1968.

${ }^{51}$ On Corbin, Scholem, Eliade and Eranos see Wasserstrom, 1999; Hakl, 2001.

52 On Portmann see Riedl, 2004, who stresses that Portmann referred to himself as a leftist.
} 
and peace'. The lectures, held in French, German, English, and sometimes in Italian, were subsequently published as the Eranos-Jahrbücher which had a high reputation among both scholars and a wider audience. ${ }^{53}$

Unlike most conferences, single lectures extended over two hours and there was no room for questions. Moreover, apparently the lecturers were expected by some to provide a particular emotional aura, beyond the customary academic form. This, it seems, was in line with an underlying agenda to explore a 'third way' beyond the dichotomies of mythos versus logos, science and scholarship vs. religion/esotericism/mysticism.

The meetings were clearly ritualized. There was a stele and the famous round table for the meeting of the electi and their 'cultic meals'. ${ }^{54}$ The elitist circle of participants has been described as a neo-gnostic cultic community and the Eranos-circle has been interpreted as representing a modern cultic milieu, deriving "its coherence and sense of common purpose essentially from a shared pattern of culture criticism directed against the "reductionist" tendencies in the modern academy' (Hanegraaff, 2001, p. 11). Others, however, stress the more prosaic scholarly nature of the gatherings as a forum for highly profiled scholars to meet and interact, and the esotericist character of the meetings is denied (Riedl, 2004). ${ }^{55}$ However that may have been, it seems that Eranos was an important point of reference and node in a wide network of scholars whose concerns went well beyond academic positivism.

By the 1950s, the Eranos-meetings had reached the peak of their reputation. By the 1980s, they seem to have outlived their 'primordial' significance and lost a great deal of their special appeal. This may well reflect larger changes in the study of religions(s) and a change of generations of scholars. The 1988 meeting was the last of its kind. Afterwards, the foundation returned to its supposed 'original project' of mediating between East and West by focusing on the Dao de-jing which had always enjoyed a special status at Eranos. But this decision was far from unanimous, and a group of scholars founded a circle known as the 'Amici di Eranos' to continue with the conferences in a slightly modified form at a nearby location. Today, both the Amici and the Eranos Foundation and the Swiss Egyptologist Erik Hornung arrange different meetings that all lay claim on the Eranos-tradition.

The decline of institutionalized Christendom and the institutional upsurge of the study of religion(s)

The 1960s and 1970s were a watershed both for the European religious landscape and the study of religion(s). This change is often expressed in terms of the secularization narrative. Even if one is critical towards this narrative, or dismisses the concept altogether, the statistical data clearly supports the idea that the earlier types of institutional religion and religiosities have lost much of their plausibility. The Scottish social and cultural historian Callum Brown observes: 'From 1956 all indices of religiosity in Britain start to decline, and from 1963 most enter free fall' (Brown, 2001 [2005], p. 188). Similar observations can be made for most European countries (with slightly varying chronologies).

The decline of institutionalized Christendom, however, did not go along with a decline in the study of religion(s). Quite to the contrary! In most European countries its fortune went on the rise. In Italy, for instance, '[t]he history of religions as a discipline fully entered into the academic studies of Italian Universities in the 1960s' (Terrin, 1998, p. 374). For the

\footnotetext{
${ }^{53}$ Immediately after the conferences, Portmann rushed off into a radio broadcasting studio in order to update the listeners on the proceedings of the conference (see Riedl, 2004, p. 117).

${ }^{54}$ Riedl, 2004, p. 116 paints a much more prosaic pictures of the conversations at the 'round table'; according to him, these conversations were about academic gossip as much as on high scholarship.

${ }^{55}$ For different conflicting interpretations see Hakl, 2001, pp. 374-389.
} 
Netherlands, it has been pointed out that the change from orthodox-exclusive to liberalinclusive Christian theology paved the way for the introduction of a non-confessional and also non-apologetic study of religion(s) in several theological institutes during the 1960s (Platvoet, 2002 , p. 130). At the beginnings of the 1970s there occurred 'a silent and quiet transformation of faculties of theology into faculties for the science of religions' (Wiegers, 2002b, p. 25). In France, at the Sorbonne's Faculty of Arts, a chair of history of religions and religious anthropology was for the first time established in 1970 in order to bridge the different areas of specialization, and subsequently a department was created (Meslin, 2002, p. 43). At English universities, '[i]n the mid-1950s there were no more than sixteen people teaching religions other than Christianity' (Cunningham, 1990, p. 21). Nowadays, there are at least as many relevant departments, and several departments of theology or divinity have added Religious Studies to their names (Cunningham, 1990, p. 24). Similar expansions can be noted throughout Europe, albeit sometimes setting on slightly later. For Denmark, current IAHR secretary general Tim Jensen (b. 1950), describes the dramatically shifting climate in a vivid manner: In 1970 there were two departments (in Copenhagen and Aarhus) with a staff of two and a student body of ten each; in 2000 there were three departments (Odense being the third), a total staff of more than 10 and a student body of 1000 undergraduate and graduate students (Jensen, 2002, pp. 183-184).

Apart from religious, academic, and ideological changes, however, the main stimulus for the unprecedented success of the academic subject resulted from a massive increase in the number of tertiary educational institutions (see also Alles, 2007, p. 306) and the corresponding transformation of the universities from an elitist to a mass institution and the corresponding expansion of the university system. This has led to a dramatic increase in the number of students and the establishment of several new chairs or even departments at old or new Universities. In Britain, for example, this process resulted in the introduction of two prominent pioneering departments - at the new university of Lancaster (1967) and at the Open University (1971). In Scotland, some pioneering efforts to establish Religious Studies outside Schools of Divinity were undertaken during the 1970s and 1980s, but came to be reversed after the dramatic cuts in university funding that affected British universities during the mid 1980s (Cox/Sutcliffe, 2006). These cuts put several departments in Britain in a state of crisis if not extinction, a process that was enforced by the Research Assessment Exercises - since 1986 regularly conducted in order to review the research output of universities in the UK - which has lead to the closure of several departments (including Derby, Sunderland, and Winchester). In Sweden, in the 1990s the government policy of creating regional colleges, some of which were later granted university status, has led to an increase in departments at new colleges and universities (Falun, Gävle), while the traditional departments (Uppsala, Lund) were suffering from inadequate funding. In Norway, one department was created in the 1960s (Bergen 1967) and two in the late 1990s (Tromsø and Trondheim).

\section{The avoidance of Christianity and changing constituencies}

Established and mainstream Christianities generally are a blind-spot in the study of religion(s). (In institutional terms, the $5^{\text {th }}$ Section of the EPHE is an important exception.) ${ }^{56}$ Wherever Christianity was studied impartially in Religionswissenschaft, ${ }^{57}$ more often than not this study operated with patterns deeply imbued by theological discourse (Hjelde, 1994). Thematically,

\footnotetext{
${ }^{56}$ At the EPHE, chairs for the history of Protestantism and the history of modern and contemporary Catholicism were created in 1943 and 1952 respectively. Further diversifications were added subsequently.

${ }^{57}$ Sharpe, 2005, p. 40 even complains that Christianity was 'frequently denied a fair hearing' by scholars of religion.
} 
such studies of Christianity predominantly focused on its interference with other religions during its formative period; heretical, dissident, and sectarian movements; or 'folk' varieties. In latter decades, the study of non-European Christianities, especially African Christianities, and Pentecostalism increasingly attracted attention, while the study of other contemporary variant and marginal Christian groups in the West is in many contexts still mainly provided by anti-cultist or confessional (mainstream Christian) research agencies. ${ }^{58}$

Early historians of religions operated in a largely Christian environment and occasionally faced opposition from religious quarters. There were even attempts to prevent the 1955 international conference from taking place in Rome, the capital of Catholicism. Nowadays, however, Western European scholars of religion move in public spaces largely devoid of Christian concerns and the student constituency of the field is mostly non-committed to Christianity or even un-churched. This implies that teachers have to address an audience of religious outsiders and analphabets for whom religious sentiments and experiences, ritual competency, knowledge of dogmas, myths and narratives and other forms of fluency in religious language-games can no longer be taken for granted. Many departments also face a good numbers of spiritual seekers looking for inspiration for their personal spiritual quest and consumption. This, together with a growing awareness of the importance of religion for world affairs has since around the late 1980s at many places led to a tremendous increase in the number of students in Religious Studies departments.

Not all universities were able or inclined to increase the number of staff accordingly. In Germany, Switzerland and Austria the situation was particularly severe. There departments rarely have more than one or two full-time positions, resulting in excessive work-loads. At several universities in Germany the students at the departments of Religionswissenschaft have started to outnumber the students at the confessional Faculties of Theology; theologians on the faculty, however, outnumber scholars of religion by sometimes 10 to 1. Similar situations exists in some other countries, among them Sweden and Switzerland. In fights over the allocation of resources and public legitimacy the study of religion(s) is often directly affected by theology's struggle for academic survival. In the Netherlands, for instance, crises in theology have led to various changes in the academic setting of the study of religion(s) at different universities (Platvoet, 1998, pp. 344-345). In Sweden, the financial crises of leading Faculties of Theology (Uppsala and Lund), resulted in a decrease in professorships in the study of religion(s) - although the general study of religion attracted the majority of students to these Faculties in the first place. In Germany some theologians have tried to jump on the bandwagon by reinventing theology as science of religion. Similar developments occurred in Britain. For Scotland James Cox and Steve Sutcliffe have recently deplored the fact ' $[\mathrm{t}]$ hat, for the most part, Religious Studies in Scottish universities remains dominated by theological disciplines', reflecting 'that the tradition of Divinity in Scotland has maintained a firm power base' preventing Religious Studies to take off as an independent discipline and field of study (Cox/Sutcliffe, 2006, p. 25). They also bemoan a 'continuing tension of Religious Studies with Divinity' (Cox/Sutcliffe, 2006, p. 25). On the continent the relations between theologies and the history of religions likewise were and are not always harmonious. At several places on the continent bitter animosities are the order of the day. The relationships between theology and Religionswissenschaft remain a standard topic in identificatory scholarly literature in those countries where theology is established at state universities (e.g., Edsman, 1974; Colpe, 1980; Antes, 1996; Jensen/Widmann/Geertz, 1996; Hjelde, 1998; Löhr, 2000; Delgado, 2003; Figl, 2003: 51-54; Kippenberg, 2003; Cox, 2006, pp. 215-218).

The international conference held in Marburg in 1960 seems to have been a critical turningpoint where the study of religion(s) emphatically separated from religious and theological

\footnotetext{
${ }^{58}$ See Arweck, 2006, for a comparative study of Anti-Cult Movements in Britain and Germany.
} 
agendas. As a reaction to a keynote-lecture by then IAHR general secretary Claas Jouco Bleeker (1898-1983) on 'The Future Task of the History of Religions' (Bleeker, 1960), R.J. Zwi Werblowsky drafted a manifesto defining five 'basic minimum presuppositions for the pursuit of our studies' (Schimmel, 1960, p. 235). The second of these presuppositions begins: 'Religionswissenschaft understands itself as a branch of the Humanities. It is an anthropological discipline, studying the religious phenomenon as a creation, feature and aspect of human culture' (Schimmel, 1960, p. 236). The statement was not included in the official congress report and ignored by the members of the old school, but a number of prominent scholars in the field including Bianchi, Brandon, Brelich, Eliade, Lanternari, and Marcel Simon ${ }^{59}$ allowed their names to be associated with 'the general tenor' of this statement which pulled the rug out from under any theological understanding of the history of religions. ${ }^{60}$

\section{Changing religious background of the scholars}

Up until the 1970s or 1980s, apart from some few Jews, atheists, neo-pagans, and religiously uncommitted, the majority of scholars of religion, even in its non-confessional variety, were committed Christians of various persuasions, even though they sometimes stood outside the framework of the respective orthodoxies and religious mainstreams. Prominent examples include Otto's liberal mystic religiosity and his Religiöser Menschheitsbund (Religious League of Humanity) (see Alles, 1991; Obergethmann 1998) founded in 1920. Another example from the post-war period is the ecumenical and religious activities of Friedrich Heiler and his project of 'evangelical catholicity' which created some stir in Marburg. In postwar Germany, Heiler was something like the figurehead of religiously committed yet politically correct study of religion. ${ }^{61}$

Beyond Germany, James Cox has recently reminded us of the African and missionary (cum colonial) roots of some main protagonist of the post World War II study of religion in Britain (Cox, 2006, pp. 141-159). Both Andrew Walls (b. 1928) and Geoffrey Parrinder (1910-2005) had held academic positions in Africa before joining British universities in the 1950 and 1960s respectively. Moreover, both had been missionaries of the Methodist church. Parrinder taught comparative religion at King's College London from 1958 to 1977 . He wrote 29 single-authored books including a work entitled What World Religions Teach (1963). In this bestseller, sketches of the teachings of a good number of religions are followed by a chapter in which Parrinder points to several teachings of non-Christian religions that serve to 'recall' neglected elements of Christianity ('What we can learn from other Faiths') before proceeding to point of the distinctive elements of Christianity ('What Christianity offers'). The theological agenda of the book is made even more explicit in a postscript to the 1968 edition, where Parrinder puts forward the following claim: 'In the study of other religions a personal faith is necessary, and here a believer is a better scientist than an agnostic' (Parrinder, 1968, p. 213). Hence, for Parrinder the study of religion is basically a religious and theologian affair. Accordingly, the book concludes with an explicit confession of faith (Parrinder, 1968, p. 214). Also in other publications he developed a religious approach to the study of religion (Cox,

\footnotetext{
${ }^{59}$ Marcel Simon (1907-1986), a historian of Christianity, had been expelled from the University of Strasbourg during the Nazi-German occupation. He served as president of the IAHR from 1970-1980, succeeded by Schimmel.

${ }^{60}$ For the Marburg conference and its significance see Sharpe, 1997, pp. 276-278.

${ }^{61}$ For a critical evaluation of Heiler's scholarly work see Waardenburg, 1992. Heiler's reputation had not been affected during the Nazi period. After the war, he tried to help some compromised colleagues to regain acceptance in the scholarly community, especially in the context of the Marburg conference (1960); see Junginger, 2008b, pp. 163-166.
} 
2006, pp. 150-153). ${ }^{62}$ Andrew Walls, who succeeded Parrinder as President of the British Association for the History of Religions, is mainly known for his work at the Center for the Study of Christianity in the Non-Western World, founded on his initiative in 1982 in the University of Aberdeen, but transferred to Edinburgh in $1987 .{ }^{63}$ Walls' work mainly focused on mission and processes of cultural interaction and translation. While often arguing from a Christian theologian point of view, he also sought to establish the study of religion(s) by assigning it a place 'that was neither purely social scientific nor theological' (Cox, 2006, p. 158). As many scholars of his generation, he 'adopted a sympathetic approach to the study of religion that privileged the perspective of believers' (Cox, 2006, p. 158).

The Dutch scholar, Jan G. Platvoet (b. 1935), who also works on Africa, started his career as a Catholic missionary in Ghana. In order to reflect on his own subjectivity as a scholar, he explicitly included an autobiographical statement in one of his main works (Platvoet, 1982, pp. 20-23). ${ }^{64}$ According to the testimony of his son, Michael Pye (b. 1939), a past president of the IAHR (1995-2000), got interested in the religions of Japan thanks to his running of bible classes while working as an English teacher in Tokyo in the early 1960s (R. Pye, 2004, p. 30). Both his predecessor and successor as president of the IAHR, the Italian Ugo Bianchi and the German Peter Antes (b. 1942), did not conceal their Catholic backgrounds. Julien Ries (b. 1920) even is a Catholic priest (Abbé).

Such forms of Christian commitment are the exception rather than the rule among the younger generation of post World War II Baby Boomers. In this respect, scholars of religion are not much different from the rest of the Western European population. It may be anecdotal, but I would know of very few colleagues who entered the profession during the past decade or so with a clearly recognizable or even public Christian profile, whereas several colleagues are known to be pagans, witches, shamans, esotericists, secular humanists, human rights activists, or atheists. Again others are religiously indifferent or 'unmusical' (Max Weber) and/or their intellectual curiosity is neither nourished nor paralleled by a personal religious commitment or quest. ${ }^{65}$ The implicit endurance of Christian and ethnocentric preconceptions in scholarly discourse notwithstanding, the scholarly community and the study of religion(s) have to a great extent been de-Christianized.

\section{Acknowledgments}

For acknowledgments (in particular to Greg Alles and Giovanni Casadio) see part I of this article and several footnotes to the present article.

\section{References}

Aletti, M., 1992. The psychology of religion in Italy. International Journal for the Psychology of Religion 2, 171189.

Alles, G.D., 1991. Rudolf Otto and the politics of utopia. Religion 21, 235-256.

Alles, G.D., 2007. Afterword: toward a global vision of religious studies, in: Alles, G. D. (ed.), Religious Studies: a global view. Routledge, London, New York, 301-322.

\footnotetext{
${ }^{62}$ Similar religionist positions can be found amongst several contemporary Scottish scholars, see Cox/Sutcliffe, 2006.

${ }^{63}$ See Cox/Sutcliffe, 2006, for the details.

${ }^{64}$ In this book, Platvoet attempts to lay the ground for a new (limitative) comparative study of religion. Unfortunately, the book has been all but ignored in the recent international upsurge of literature on this issue.

${ }^{65}$ In this context, it may be appropriate to spell out my own position. I am a Roman Catholic, but presently regard myself as belonging rather than as believing.
} 
Antes, P., 1996. Theologie und Religionswissenschaft, in: Risse, G. (ed.), Wege der Theologie: an der Schwelle zum dritten Jahrtausend. Festschrift für Hans Waldenfels zur Vollendung des 65. Lebensjahres. Bonifatius, Paderborn, 313-319.

Anttonen, V. Comparative religion at the University of Turku and the University of Helsinki: a brief survey. [http://www.sus.utu.fi/english/turkuhelhist.htm]

Arweck, E., 2006. Researching New Religious Movements: responses and redefinitions. Routledge, London, New York.

Bäckström, A., Edgarth Beckman, N., Petterson, P., 2004. Religious Change in Northern Europe: the case of Sweden. Verbum, Stockholm.

Bauschulte, M., 2007. Religionsbahnhöfe der Weimarer Republik. Studien zur Religionsforschung 1918-1933. diagonal, Marburg.

Beckford, J.A., 2006. The sociology of religion in the Nordic Region as seen from the other side of the North Sea. Nordic Journal of Religion and Society 19, 1-11.

Belzen, J.A., 2002. Developing scientific infrastructure: The International Association for the Psychology of Religion after its reconstitution. Psychology of Religion Newsletter. American Psychological Association Division 36 27, 1-12.

Beltzen, J.A., 2005. Methodological concerns in the psychology of religion: continuities, losses and transforming perspectives. Religion 35, 137-165.

Benavides, G., 2001. Jakob Wilhelm Hauer, or Karmayoga as a Cold War weapon, in: Doležalová, I., Martin, L. H., Papoušek, D. (Eds), The Academic Study of Religion during the Cold War: East and West. P. Lang etc., New York, 225-238.

Bleeker, C.J., 1955. Important decisions taken at the Congress in Rome. Numen 2, 236-240.

Bleeker, C.J., 1960. The future task of the history of religions. Numen 7, 221-234.

Brown, C.G., 2001 (2005). The Death of Christian Britain: understanding secularisation, 1800-2000. Routledge, London.

Cunningham, A., 1990. Religious Studies in the universities - England, in: King, U. (ed.), Turning points in Religious Studies: essays in honour of Geoffrey Parrinder. T\&T Clark, Edinburgh, 21-31.

Colpe, C., 1980. Theologie, Ideologie, Religionswissenschaft. Demonstrationen ihrer Unterscheidung. C. Kaiser, München.

Cox, J.L., 2006. A Guide to the Phenomenology of Religion: key figures, formative influences, and subsequent debates. T\&T International, London, New York.

Cox, J.L., Sutcliffe, S., 2006. Religious studies in Scotland: a persistent tension with divinity. Religion 36, 1-28.

Delgado, M., 2003. Religionswissenschaft und Theologie. Zeitschrift für Missionswissenschaft und Religionswissenschaft 87, 1-2.

Diez de Velasco, F., 1995. La Historia de las Religiones en España: avatres de una disciplina. 'Ilû 0, 51-61.

Diez de Velasco, F., 2002 (1998, 1995). Introducción a la Historia de las Religiones. Tercera edición revisada y aumentada. Trotta, Madrid.

Diez de Velasco, F., 2005. La historia de las religiones: métodos y perspectivas. Akal, Madrid.

Diez de Valesco, F., 2007. Ángel Álvarez de Miranda y la cátedra de Historia de las Religiones de la Universidad de Madrid: un proyecto truncado. Bandue 1, 83-133.

Doležalová, I., Martin, L.H., Papoušek, D. Eds. 2001, The Academic Study of Religion during the Cold War: East and West, P. Lang etc., New York.

Dumont, L., 1967. Homo hierarchicus: essai sur le sysème des castes. Gallimard, [Paris].

Edsman, C.-M., 1974. Theology or Religious Studies. Religion 4, 59-74.

Evans-Pritchard, E.E., 1965. Theories of Primitive Religion. Clarendon Press, Oxford.

Evans-Pritchard, E.E., 1937. Witchcraft, Oracles and Magic among the Azande. Clarendon Press, Oxford.

Evens, T.M.S., Handelman, D. eds 2006, The Manchester School: practice and ethnographic praxis in anthropology, Berghahn Books, New York.

Fardon, R., 1999. Mary Douglas: an intellectual biography. Routledge, London, New York.

Figl, J., 2003. Einleitung. Religionswissenschaft - Historische Aspekte, heutiges Fachverständnis und Religionsbegriff, in: Figl, J. (ed.), Handbuch Religionswissenschaft. Religionen und ihre zentralen Themen. Tyrolia/Vandenhoeck \& Ruprecht, Innsbruck, Wien, Göttingen, 17-80.

Fuller, C.J., 1992. The Camphor Flame: popular Hinduism and society in India. Princeton University Press, Princeton.

Geels, A. , Wikström, O., 2006. Den religiösa människan: en introduktion till religionspsykologin. Natur och kultur, Stockholm.

Gellner, D.N., 1999. Anthropological approaches, in: Connolly, P. (ed.), Approaches to the Study of Religion. Continuum, London, New York, 10-41.

Hakl, H.T., 2001. Der verborgene Geist von Eranos. Unbekannte Begegnungen von Wissenschaft und Esoterik. Eine alternative Geistesgeschichte des 20. Jahrhunderts. Verlag Neue Wissenschaft, Bretten. 
Hanegraaff, W.J., 2001. Beyond the Yates Paradigm: The Study of Western Esotericism between counterculture and new complexity. Aries 1, 5-37.

Heelas, P., 1996. The New Age Movement: the celebration of the self and the sacralization of modernity. Blackwell, Oxford.

Heelas, P., Woodhead, L., 2005. The Spiritual Revolution: why religion is giving way to spirituality. Blackwell, Malden.

Heiler, F., 1923. Das Gebet. Eine religionsgeschichtliche und religionspsychologische Untersuchung. 5. Auflage. Reinhardt, München.

Helve, H., 2004. A Viewpoint concerning the Study of Religions in Finland. In: Kleine, C., Schrimpf, M., Triplett, K. (Eds), Unterwegs. Neue Pfade in der Religionswissenschaft. Festschrift für Michael Pye zum 65. Geburtstag. Biblion Verlag, München, pp. 219-29.

Henning, C., 2000. Zankapfel Psychoanalyse, in: Henning, C., Nestler, E. (Eds), Religionspsychologie heute. Lang, Frankfurt am Main, 67-102.

Henning, C., 2003. Die Geschichte der Religionspsychologie im deutschsprachigen Raum, in: Henning, C., Murken, S., Nestler, E. (Eds), Einführung in die Religionspsychologie. Ferdinand Schöningh, Paderborn, 9-90.

Henninger, J., Ciattini, A., 2005. Schmidt, Wilhelm. Encyclopedia of Religion. Second Edition 12, 8167-8171.

Hjelde, S., 1994. Die Religionswissenschaft und das Christentum. Eine historische Untersuchung über das Verhältnis von Religionswissenschaft und Theologie. Brill, Leiden.

Hjelde, S., 1998. Religionswissenschaft und Theologie: Die Frage ihrer gegenseitigen Abgrenzung in historischer Perspektive. Studia Theologica - Scandinavian Journal of Theology 52, 85-102.

Holm, N.G., 1997. An integrated role theory for the psychology of religion: concepts and perspectives, in: Spilka, B., McIntosh, D. N. (Eds), The Psychology of Religion: theoretical approaches. Westview Press, Boulder, 73-85.

Holm, N.G., 2002. Religionspsykologins grunder. Åbo akademi, Åbo.

Holm, N.G., Religionsvetenskap vid Åbo Akadem [sic]. [http://www.sus.utu.fi/svenska/abo.htm]

Holm, N.G. , Belzen, J.A. eds 1995, Sundén's Role Theory: an impetus to contemporary psychology of religion, Åbo Akademi, Åbo.

Hvidtfeldt, A., 1961. Religioner og kulturer. Nogle hovedtræk af den almindelige religionshistorie. Munksgaard, [København].

Irion, U., 1989, Religiosität ohne Religion. Rudolf Otto, Rudolf Bultmann, Klaus Heinrich, Mircea Eliade, in: Kemper, P. (ed.), Macht des Mythos - Ohnmacht der Vernunft? Fischer Taschenbuch Verlag, Frankfurt am Main, 289-309.

Jensen, T., 2002. From History of Religions to the Study of Religions. Trends and tendencies in Denmark, in: Sfameni Gasparro, G. (ed.), Themes and Problems of the History of Religions in Contemporary Europe. Proceedings of the International Seminar Messina, March 30-31 2001 / Temi e problemi della Storia delle Religioni nell'Europa contemporanea. Atti del seminario Internazionale Messina, 30-31 Marzo 2001. Edizioni Lionello Giordano, Cosenza, 183-208.

Jensen, S., Widmann, P., Geertz, A.W. Eds. 1996, Medspil og modspil: teologi og religionsvidenskab, Det Teologiske Fakultet, Århus.

Junginger, H., 1999. Von der philologischen zur völkischen Religionswissenschaft. Das Fach Religionswissenschaft an der Universität Tübingen von der Mitte des 19. Jahrhunderts bis zum Ende des Dritten Reiches. Steiner, Stuttgart.

Junginger, H., 2008a. Introduction, in: Junginger, H. (ed.), The Study of Religion under the Impact of Fascism. Brill, Leiden, 1-103.

Junginger, H., 2008b. From Buddha to Adolf Hitler: Walter Wüst and the Aryan tradition, in: Junginger, H. (ed.), The Study of Religion under the Impact of Fascism. Brill, Leiden, 107-177.

Kääriäinen, K., Niemelä, K., Ketola, K., 2005. Religion in Finland: decline, change and transformation of Finnish religiosity. Research Institute of the Lutheran Church in Finland, Tampere.

Kippenberg, H.G., 1991. Die vorderasiatischen Erlösungsreligionen in ihrem Zusammenhang mit der antiken Stadtherrschaft. Heidelberger Max-Weber-Vorlesungen 1988. Suhrkamp, Frankfurt am Main.

Kippenberg, H.G., 2002. Religiöse Gemeinschaften. Wo die Arbeit am Sinn-Problem der Welt und der Bedarf sozialen Handelns an Gemeinschaftlichkeit zusammenkommen, in: Albert, G., Bienfait, A., Sigmund, S., Wendt, C. (Eds.), Das Weber-Paradigma. Studien zur Weiterentwicklung von Max Webers Forschungsprogramm. Mohr Siebeck, Tübingen, 211-233.

Kippenberg, H.G., 2003. Theologie - Religionswissenschaft: Ist eine komplementäre Konstruktion denkbar?, in: Nowak, K., Oexle, O. G., Rendtorff, T. , Selge, K.-V. Eds., Adolf von Harnack. Christentum, Wissenschaft und Gesellschaft. Wissenschaftliches Symposium aus Anlaß des 150. Geburtstags. Vandenhoeck \& Ruprecht, Göttingen, 289-297.

Kippenberg, H.G., Riesebrodt, M. (Eds.), 2001, Max Webers 'Religionssystematik', Mohr Siebeck Tübingen. 
Komulainen, J., 2005. An Emerging Cosmotheandric Religion? Raimon Panikkar's pluralistic theology of religions. Brill, Leiden.

Lease, G., 1997. Hans-Joachim Schoeps, in: Gilman, S. L., Zipes, J. D. (Eds), Yale Companion to Jewish Writing and Thought in German Culture, 1096-1996. Yale University Press, New Haven, 655-661.

Leitāne, I., 2008. Haralds Biezais (1909-1995): Ein Religionshistoriker zwischen Theologie und Religionswissenschaft, in: Junginger, H. (ed.), The Study of Religion under the Impact of Fascism. Brill, Leiden, 511-542.

Löhr, G. ed. 2000, Die Identität der Religionswissenschaft. Beiträge zum Verständnis einer unbekannten Disziplin, Lang, Frankfurt am Main, Berlin, Bern, Wien.

Martin, L.H., 2001. The academic study of religions during the Cold War: a Western perspective, in: Doležalová, I., Martin, L. H. , Papoušek, D. (Eds), The Academic Study of Religion during the Cold War: East and West. P. Lang etc., New York, 209-223.

McCutcheon, R.T., 2004. 'Just follow the money': the Cold War, the humanistic study of religion, and the fallacy of insufficient cynicism. Culture and Religion 5, 41-69.

Mejido, M.J., 2004. On the genesis and transformations of Social Compass. Social Compass 51, 23-44.

Meslin, M., 2002. Histoire ou science des religions: le cas français, in: Wiegers, G. (ed.), Modern Societies \& the Science of Religions. Studies in honour of Lammert Leertouwer. Brill, Leiden, 39-54.

Mischek, U., 2008. Antisemitismus und Antijudaismus in den Werken und Arbeiten Pater Wilhelm Schmidt's S.V.D. (1868-1954), in: Junginger, H. (ed.), The Study of Religion under the Impact of Fascism. Brill, Leiden, 107-177.

Obergethmann, F., 1998. Rudolf Ottos »Religiöser Menschheitsbund« - ein Kapitel interreligiöser Begegnung zwischen den Weltkriegen. Zeitschrift für Religionswissenschaft 6, 79-106.

Parrinder, E.G., 1968. What World Religions Teach. Second edition enlarged. George G. Harrap, London, Toronto, Wellingdon, Sydney.

Pentikäinen, J., 2005. Honko, Lauri. The Encyclopedia of Religion. Second edition 6, 4122-4123.

Platvoet, J.G., 1982. Comparing Religions: a limitative approach. An analysis of Akan, Para-Creole, and IFOSananda rites and prayers. Mouton, The Hague.

Platvoet, J., 1998. From consonance to autonomy: the Science of Religion in the Netherlands, 1949-1995. Method \& Theory in the Study of Religion 10, 334-351.

Platvoet, J., 2002. Pillars, Pluralism and secularization: a social history of Dutch Sciences of Religion, in: Wiegers, G. (ed.), Modern Societies \& the Science of Religions: studies in Honour of Lammert Leertouwer. Brill, Leiden, 82-148.

Pye, M., 2001. Political correctness in the study of religions: is the Cold War really over?, in: Doležalová, I., Martin, L. H. , Papoušek, D. (Eds), The Academic Study of Religion during the Cold War: East and West. P. Lang etc., New York, 313-333.

Pye, R., 2004. Journeys with my father, in: Kleine, C., Schrimpf, M., Triplett, K. (ed.), Unterwegs. Neue Pfade in der Religionswissenschaft. Festschrift für Michael Pye zum 65. Geburtstag. Biblion Verlag, München, 29-34.

Riedl, M., 2004. Adolf Portmann - Ein Skeptiker auf der Suche, in: Barone, E., Riedl, M., Tischel, A. (Eds), Pioniere, Poeten, Professoren. Eranos und der Monte Verità in der Zivilisationsgeschichte des 20. Jahrhunderts. Königshausen \& Neumann, Würzburg, 115-126.

Rudolph, K., 1992. Geschichte und Probleme der Religionswissenschaft. E.J. Brill, Leiden.

Saraglou, V. , Hutsebaut, D. ed. 2001, Religion et développement humain: Questions psychologiques, L'Harmattan Paris, Montréal.

Schimmel, A., 1960. Summary of the discussions. Numen 7, 235-239.

Schimmel, A., 2005. Andrae, Tor. Encyclopedia of Religion. Second Edition 1, 333-334.

Schoeps, H.-J., 1959. Was ist und was will die Geistesgeschichte? Über Theorie und Praxis der Zeitgeistforschung. Musterschmidt, Göttingen.

Schoeps, H.-J., 1961. Religionen. Wesen und Geschichte. Bertelsmann, Gütersloh.

Schoeps, J., 2000. Nil inultum remanebit. Die Erlanger Universität und ihr Umgang mit dem deutsch-jüdische Remigranten Hans-Joachim Schoeps (1909-1980). Zeitschrift für Religions- und Geistesgeschichte 52, 266-278.

Sharpe, E.J., 1997 (1986; 1975). Comparative Religion: a history. Open Court, Chicago, La Salle.

Sharpe, E.J., 2005. The study of religion in historical perspective, in: Hinnells, J. R. (ed.), Routledge Companion to the Study of Religion. Routledge, London, 21-45.

Stausberg, M., 2007. The study of religion(s) in Western Europe (I): Prehistory and history until World War II. Religion 37, 294-318.

Stuckrad, K.v., 2003. From ancient religions to modern scholarship: the work of Hans G. Kippenberg. Religious Studies Review 29, 261-266.

Sundén, H., 1959. Religionen och rollerna: ett psykologiskt studium av fromheten. Diakonistyrelsen, Stockholm. 
Sundén, H., 1981. Religionspsykologi: problem och metoder. Proprius, Stockholm.

Tambiah, S., 2002. Edmund Leach: an anthropological life. Cambridge University Press, Cambridge.

Terrin, A.N., 1998. The Study of Religions in Italy: some data and reflections. Method \& Theory in the Study of Religion 10, 373-387.

Voyé, L., 2004. A survey of advances in the sociology of religion, in: Antes, P., Geertz, A. W., Warne, R. R. (Eds), New Approaches to the Study of Religion. Volume 2: Textual, Comparative, Sociological, and Cognitive Approaches. Walter de Gruyter, Berlin, New York, 195-228.

Waardenburg, J., 1992. Friedrich Heiler und die Religionsphänomenologie - eine kritische Würdigung. Marburger Universitätsreden 18, 21-51.

Wasserstrom, S.M., 1999. Religion after Religion: Gershom Scholem, Mircea Eliade, and Henry Corbin at Eranos. Princeton University Press, Princeton.

Whaling, F., 1985. Contemporary Approaches to the Study of Religion. Volume II: the social sciences. Mouton, Berlin, New York, Amsterdam.

Wiebe, D., 2001. Religious Studies in North America during the Cold War, in: Doležalová, I., Martin, L. H., Papoušek, D. (Eds.), The Academic Study of Religion during the Cold War: East and West. P. Lang etc., New York, 267-285.

Wiegers, G., 2002a. The Science of Religion in Spain: The Institituto Universitario de Ciencias de las Religiones in Madrid and Ibn Rushd University in Córdoba, in: Wiegers, G. (ed.), Modern Societies \& the Science of Religions. Studies in Honour of Lammert Leertouwer. Brill, Leiden, 166-184.

Wiegers, G., 2002b. Introduction. The Science of Religion: its social functions and applications in a changing world, in: Wiegers, G. (ed.), Modern Societies \& the Science of Religions. Studies in honour of Lammert Leertouwer. Brill, Leiden, 17-38.

Wikström, O., 2000. The psychology of religion in Scandinavia, in: Henning, C., Nestler, E. (Eds), Religionspsychologie heute. Lang, Frankfurt am Main, 29-57.

Wulff, D.M., 1991. Psychology of Religion: classic and contemporary views. Wiley, New York.

Zerries, O., Ciattini, A., 2005. Jensen, Adolf E. Encyclopedia of Religion. Second Edition 12, 4824-4826. 